Dermatology 2008;217:284-285

DOI: $\underline{10.1159 / 000150603}$

\section{Rapid Onset and Fatal Outcome of Two Squamous Cell Carcinomas of the Genitalia in a Patient Treated with Etanercept for Cutaneous Psoriasis}

\author{
Christelle Comte, Jean-Jacques Guilhou, Bernard Guillot, \\ Olivier Dereure
}

Department of Dermatology, Hôpital Saint-Eloi, University of Montpellier, Montpellier, France

\section{Key Words \\ Etanercept $\cdot$ Penis $\cdot$ Squamous cell carcinoma, metastasis}

The hazard of developing skin or mucous membrane tumors during anti-TNF- $\alpha$ treatment remains a debated topic but largescale cohort surveys did not substantiate this possibility so far for rheumatoid arthritis and Wegener's granulomatosis patients despite alarming, though individual reports [1-3]. However, the more recent use of these therapeutics in psoriasis patients raises this question in more critical terms due to the previous use in this subset of patients of immunosuppressive or potentially carcinogenic therapies such as phototherapy, methotrexate, ciclosporine or coaltar, as illustrated by the rapid onset of penile cutaneous squamous cell carcinoma (SCC) in a patient receiving etanercept for psoriasis [4]. We hereby report on a similar observation emphasizing this potential risk.

A 71-year-old patient without any other significant medical background had been treated for more than 30 years for a widespread cutaneous psoriasis with several topical treatments, phototherapy (PUVA and UVB with protection of the genitals for the most recent treatments) and systemic drugs (retinoids, ciclosporine, methotrexate, salazopyrine and eventually etanercept $25 \mathrm{mg}$ twice a week with a good clinical result). A first cutaneous epidermoid carcinoma was diagnosed on the right thigh in 1994 with no subsequent relapse. Thirty-four months after etanercept had been introduced, 2 nodular and infiltrated lesions of the penile and the scrotal area of 5 and $15 \mathrm{~mm}$ in diameter, respectively, appeared almost simultaneously and rapidly grew in size. No regional lymph node enlargement was initially present. Histological examination of both lesions disclosed an ill-differentiated infiltrating SCC. A search for HPV infection using in situ hydridization and specific PCR was conducted on both lesions and proved negative. Clinical and morphological staging was unremarkable, and both lesions were surgically removed with a $1-\mathrm{cm}$ margin. Etanercept was interrupted but a large metastatic inguinal lymph node developed 9 months after primary tumor excision. A complete inguinal dissection was then carried out after tumoral reduction by chemotherapy with carboplatin and gemcitabine. Three months after regional surgery, metastatic lymph nodes of the same location progressively recurred with invasion of the femoral vein; the patient finally died 16 months after the initial diagnosis.

Anti-TNF- $\alpha$ agents durably inhibit the development of the cytotoxic T-cell response which plays a central role in tumor promotion and progression control and this biological effect might increase the hazard of malignancy or the aggressivity of tumors as a consequence. In this perspective, the report of 7 cutaneous SCCs of rapid onset in 5 rheumatoid arthritis patients receiving etanercept for a limited period of time was initially worrisome regarding a higher risk of cutaneous tumors, but no additional case was reported since then with the noticeable exception of a penile SCC in a patient receiving etanercept for psoriasis [4]. However, previous exposure to high doses of UVA or UVB and/or to other immunosuppressive agents such as ciclosporine for psoriasis probably delineates a special subset of patients at higher risk of developing SCC when compared to other indications such as rheumatoid arthritis, the genital area being perhaps the more significant target as already reported in psoriasis [5] and as illustrated both by our observation and by the report of Fryrear et al. [4]. The hypothesis of a previous but latent infection by oncogenic strains of HPV can be raised as well since the onset of genital HPV lesions occurring in patients receiving anti-TNF- $\alpha$ agents has recently been reported [6]; however, no clue for the presence of HPV sequences was present in our patient. The delay between anti-TNF- $\alpha$ introduction and the occurrence of genital mucous membrane SCC was longer in both patients than in the report of Smith and Skelton [3] but not inconsistent with the usual process of carcinogenesis. Owing to the pharmacological profile of these molecules, other clinical features might be more frequent in antiTNF- $\alpha$-associated cutaneous SCC such as multiple tumors, rapid local growth and perhaps a higher metastatic potential, all characteristics featured by our patient. On the other hand, it is of interest to note that the use of efalizumab, another non-anti-TNF- $\alpha$ biological agent currently used in psoriasis, has not been linked to a significant increase in the patients' risk of developing skin malignancies [7] although the occurrence of multiple dermatofibromas, a cutaneous condition sometimes also related to immunodeficiency, has recently been reported in this therapeutic setting [8]. Although definitive conclusions cannot be drawn on so few cases, a very careful examination of the whole body surface including the genitals must be carried out on a regular basis in psoriasis patients receiving anti-TNF- $\alpha$ agents. Furthermore, the patient's background must be carefully checked before considering anti-TNF- $\alpha$ treatment, and a history of skin carcinoma might

B.G. is currently involved in a clinical study using infliximab (Remicade ${ }^{\circledR}$, Schering-Plough).

\section{KARGER}

(c) 2008 S. Karger AG, Basel

Fax +41613061234

E-Mail karger@karger.ch

www.karger.com 
represent a serious limitation. Additionally, restricting the prescription of anti-TNF- $\alpha$ agents to patients who have always received maximal doses of phototherapy is perhaps not entirely adequate; should such observations become relevant in the future, they might lead to reconsidering the recommendations of antiTNF- $\alpha$ usage as a last-line therapy.

\section{References}

-1 Lebwohl M, Blum R, Berkowitz E, Kim D, Zitnik R, Osteen C, Wallis WJ: No evidence for increased risk of cutaneous squamous cell carcinoma in patients with rheumatoid arthritis receiving etanercept for up to 5 years. Arch Dermatol 2005;141:861-864.

2 Stone JH, Holbrook JT, Marriott MA, Tibbs AK, Sejismundo LP, Min YI, Specks U, Merkel PA, Spiera R, Davis JC, St Clair EW, McCune WJ, Ytterberg SR, Allen NB, Hoffman GS, Wegener's Granulomatosis Etanercept Trial Research Group: Solid malignancies among patients in the Wegener's Granulomatosis Etanercept Trial. Arthritis Rheum 2006;54:1608-1618.

- 3 Smith KJ, Skelton HG: Rapid onset of cutaneous squamous cell carcinoma in patients with rheumatoid arthritis after starting tumor necrosis factor alpha receptor IgG1-Fc fusion complex therapy. J Am Acad Dermatol 2001;45:953-956.
4 Fryrear RS 2nd, Wiggins AK, Sangueza O, Yosipovitch G: Rapid onset of cutaneous squamous cell carcinoma of the penis in a patient with psoriasis on etanercept therapy. J Am Acad Dermatol 2004;51:1026.

5 Stern RS, Bagheri S, Nichols K, PUVA Follow-Up Study: The persistent risk of genital tumors among men treated with psoralen plus ultraviolet A (PUVA) for psoriasis. J Am Acad Dermatol 2002;47:33-39.

-6 Antoniou C, Kosmadaki MG, Stratigos AJ, Katsambas AD: Genital HPV lesions and molluscum contagiosum occurring in patients receiving anti-TNF-alpha therapy. Dermatology 2008;216:364-365.

7 Leonardi CL, Toth D, Cather JC, Langley RG, Werther W, Compton P, Kwon P, Wetherill G, Curtin F, Menter A: A review of malignancies observed during efalizumab (Raptiva) clinical trials for plaque psoriasis. Dermatology 2006;213:204-214.

8 Santos-Juanes J, Coto-Segura P, Mallo S, Galache C, Soto J: Multiple eruptive dermatofibromas in a patient receiving efalizumab. Dermatology 2008;216:363.

\section{O. Dereure}

Department of Dermatology, University Hospital of Montpellier Hôpital Saint-Eloi, 80, avenue A. Fliche

FR-34295 Montpellier Cedex 5 (France)

Tel. +33467336906, Fax +33467336958

E-Mail o-dereure@chu-montpellier.fr 